\title{
The Effect of Transformation Leadership on Organizational Performance through the Strong Lecturer Engagement
}

\author{
Devi Marlita ${ }^{1}$, Adriana Madya Marampa ${ }^{2}$, Sri Murni Setyawati ${ }^{3}$ Adi Indrayanto ${ }^{4}$ \\ ${ }^{1,}$ Senior Lecturer Institut Transportasi dan Logistik Trisakti, Jakarta Indonesia, Student of Postgraduate Program, Doctoral \\ Management of Science Universitas Jenderal Soedirman, \\ 2. Senior Lecturer Universitas Kristen Indonesia, Toraja, Indonesia, Student of Postgraduate Program, Doctoral Management of \\ Science Universitas Jenderal Soedirman, \\ 3. A Professor at Postgaduate Program, Doctoral Management of Science Universitas Jenderal Soedirman \\ 4. Senior Lecturer of Postgraduate Program, Doctoral Management of Science Universitas Jenderal Soedirman, \\ 11dev.marlita@gmail.com, ${ }^{2}$ ana.marampa@yahoo.com, ${ }^{3}$ nunk_pwt@yahoo.co.id, ${ }^{4}$ adiindrayanto@gmail.com
}

\begin{abstract}
Transformational leadership is one of the leadership types that can be applied in an organization, especially for organizations in the field of education. This study was conducted on several lecturers spread across several campuses in Indonesia. The research method uses SEM- \{PLS). The results showed as follows. (1) Engagement influences performance with a T-statistic value of 4.000 (> 1.96). Furthermore, the original sample estimate value is positive that is 0.582 . Therefore, H1 is accepted. (2) There is a significant relationship between transformational leadership and engagement with a T-statistic value of 16.737 (> 1.96). Furthermore, the original sample estimate value is positive that is 0.820 . Therefore, $\mathrm{H} 2$ is accepted. (3) There is no significant relationship between the transformational leadership and performance with a Tstatistic value of $0.145(<1.96)$. Furthermore, the original sample estimate value is positive that 0.202 which indicates that the relationship between transformational leadership and performance is negative. Therefore, H3 is rejected.
\end{abstract}

Keywords:

Transformational Leadership, Engagement, Performance

Article Received: 18 October 2020, Revised: 3 November 2020, Accepted: 24 December 2020

\section{INTRODUCTION}

Humans are a very important resource in an organization that cannot be replaced by other resources. Lecturers in a university are very important. Because lecturers are teaching staff who are a resource that needs to be managed properly. One type of leadership that can be used in higher education is Transformatioanal leadership. Leadership is very important in an organization because it can determine the success or failure of an organization. The leader can mobilize everyone in an organization to achieve his desired goals. Leadership in higher education highly determines the success of the campus. This study was conducted on several lecturers from several universities in Indonesia. Furthermore, the researchers apply transformational leadership. Kahn (1990) stated that transformational leadership has a great potential to influence followers' feelings concerning psychological safety by providing a supportive environment in which they feel safe to fully engage in a task.

Buil, Martínez, \& Matute (2019) stated that transformational leadership refers to the approach used by leaders to motivate their followers by identifying organizational goals and interests. Transformational leaders behave in ways that can motivate people around them to give meaning and challenge for the work of their followers. They also stimulate their followers' efforts to be innovative and creative by questioning assumptions, reframing problems, and approaching old situations in new ways. In addition, they also pay special attention to the needs of each follower for the sake of their achievement and growth by acting as a coach or mentor. The new construct in this study is strong engagement. Based on studies conducted by Sandell (2012) and Buil, Martínez, \& Matute (2019), they indicated that workers engagement 
functions as a mediating variable between transformational leadership and performance. Strong engagement is a form of lecturers' involvement that is filled with a sense of responsibility. Strong engagement is highly important to be developed in the field of education, especially in higher education. A lecturer has great demands and responsibilities. Basically, lecturers need to be able to do the three basic pillars (Ind. Tri Dharma) of Indonesia's higher education. Leaders must be able to help lecturers so that they can stay on the campus. Strong engagement is one of those factors because, with strong engagement, those lecturers can feel accepted in that environment, feel valued at the place where they work, feel easy to cooperates with their fellow lecturers, and feel useful for others.

\section{Transformational leadership is} characterized by charisma (ideal influence), an inspirational character, motivational attitude, having intellectual stimulation, and individual consideration. Transformational leadership can be defined as a leadership style that can increase the awareness of members of an organization for the sake of the collective interest and contribute to achieving it. García-Morales et al. (2012) stated that transformational leadership can be described as a leadership style that promotes the collective interests of employees and helping them achieve those goals. In addition, transformational leaders can inspire their followers and increase followers' knowledge and learning systems that can encourage them to be innovative so that they can easily solve problems. Transformational leaders have charisma, intellectual stimulation, inspiring character, being able to enhance communication, having trust, and willing to share knowledge (Senge, 1990; Bass dan Avolio, 2000).

The purpose of transformational leadership is to increase the ability of followers to solve their problems and eventually others' problems (Avolio, Waldman, \& Einstein, 1988). Samad (2012) stated that transformational leaders integrate creative insights, persistence, and sensitivity to followers. The role of transformational leaders is to develop and inspire their subordinates to be more responsible and committed to challenging goals. Leaders convince their followers to develop themselves. Transformational leaders develop and articulate their interesting visions on future opportunities, provide constructive feedback to followers, inspire them to work on shared goals, and motivate them to create a high performance (Bass, 1985;Bass, Avolio, \& Goodheim, 1987). Transformational leadership plays an important role that can cause the changes needed for effective management. Transformational leaders can grow competencies that need to be met by providing challenges while also showing confidence and increasing the ability of followers to help them overcome personal challenges and simultaneously strengthening team spirit by articulating their visions that appeal to the team and emphasizing the importance of team goals (Kovjanic, Schuh, \& Jonas, 2013).

Bass et al. (1994) mentioned that there are four influential factors in transformational leadership, i.e. the ideal influence or inspirational motivation, intellectual stimulation, and individual considerations. The ideal influence or inspirational motivation is a motivation related to the formulation and articulation of shared vision and/or goals. Actions related to the ideal influence or inspirational motivation are instilling pride in others because of being associated with leadership, encouraging followers to go beyond self-interest for the sake of the good of the group, assuring that obstacles can be overcome, promoting self-confidence in achieving and implementing goals and tasks, speaking optimistically about the future, articulating an interesting vision for the future, and providing an interesting illustration of the change of the organization.

\section{Literatur Review}

2.1 Transformational Leadership 
Transformational leadership is characterized by charisma (ideal influence), an inspirational character, motivational attitude, having intellectual stimulation, and individual consideration. Transformational leadership can be defined as a leadership style that can increase the awareness of members of an organization for the sake of the collective interest and contribute to achieving it. García-Morales et al. (2012) stated that transformational leadership can be described as a leadership style that promotes the collective interests of employees and helping them achieve those goals. In addition, transformational leaders can inspire their followers and increase followers' knowledge and learning systems that can encourage them to be innovative so that they can easily solve problems. Transformational leaders have charisma, intellectual stimulation, inspiring character, being able to enhance communication, having trust, and willing to share knowledge (Senge, 1990; Bass dan Avolio, 2000).

The purpose of transformational leadership is to increase the ability of followers to solve their problems and eventually others' problems (Avolio, Waldman, \& Einstein, 1988). Samad (2012) stated that transformational leaders integrate creative insights, persistence, and sensitivity to followers. The role of transformational leaders is to develop and inspire their subordinates to be more responsible and committed to challenging goals. Leaders convince their followers to develop themselves. Transformational leaders develop and articulate their interesting visions on future opportunities, provide constructive feedback to followers, inspire them to work on shared goals, and motivate them to create a high performance (Bass, 1985;Bass, Avolio, \& Goodheim, 1987).Transformational leadership plays an important role that can cause the changes needed for effective management. Transformational leaders can grow competencies that need to be met by providing challenges while also showing confidence and increasing the ability of followers to help them overcome personal challenges and simultaneously strengthening team spirit by articulating their visions that appeal to the team and emphasizing the importance of team goals (Kovjanic, Schuh, \& Jonas, 2013).

Bass et al. (1994) mentioned that there are four influential factors in transformational leadership, i.e. the ideal influence or inspirational motivation, intellectual stimulation, and individual considerations. The ideal influence or inspirational motivation is a motivation related to the formulation and articulation of shared vision and/or goals. Actions related to the ideal influence or inspirational motivation are instilling pride in others because of being associated with leadership, encouraging followers to go beyond self-interest for the sake of the good of the group, assuring that obstacles can be overcome, promoting self-confidence in achieving and implementing goals and tasks, speaking optimistically about the future, articulating an interesting vision for the future, and providing an interesting illustration of the change of the organization.

\subsection{ENGAGEMENT}

Employee engagement is defined differently in the field of academic research. For some practitioners, engagement is basically illustrated as an attribute of psychological behavior (Macey \& Schneider, 2008). Employee engagement leads to individual-level loyalty and satisfaction results (Azka, Tahir, M, \& Syed, 2011). Meanwhile, working engagement provides important personal resources needed in behaving (Salanova, 2008). Kahn (1990) argued that engagement can utilize members of the organization in working roles in which they will use and express themselves physically, cognitively, emotionally, and mentally during performing their roles. M. Bakker, (2006) said that working engagement is characterized by high energy levels and can be identified with one's work. Mcbain (2006) said that employee engagement reflects changes in organizational contexts in which employees and businessmen in a psychological contract reflect motivational 
patterns that change for greater personal fulfillment in their working lives and are not solely motivated by financial rewards. Working engagement provides important personal resources needed to initiate new behavior (Salanova, 2008). Engagement is identified by the commitment to an organization or a job by applying requirements such as organizational commitment and satisfaction. Employee engagement is based on organizational culture, communication style, managerial style, leadership style, and trust (Lockwood, 2007).

According to Schaufeli, Salanova, Gonzálezromá, \& Bakker (2002) employee engagement as a condition that can motivate to work is characterized by enthusiasm, dedication, and absorption. The involved employees have an energetic and effective relationship with their working activities and see themselves able to fully handle the demands of their work. Schaufeli et al., (2002) claimed that working engagement that involves strength, dedication, and absorption shows high energy and motivation during the working activities. Dedication is characterized by a perception of meaning, inspiration, and pride in one's work. Furthermore, absorption is associated with being fully concentrated and enjoying a job in which time passes quickly and someone has difficulty getting away from the job. Employee engagement is defined differently in the field of academic research. For some practitioners, engagement is basically illustrated as an attribute of psychological behavior (Macey \& Schneider, 2008). Employee engagement leads to individuallevel loyalty and satisfaction results (Azka, Tahir, M, \& Syed, 2011). Meanwhile, working engagement provides important personal resources needed in behaving (Salanova, 2008). Kahn (1990) argued that engagement can utilize members of the organization in working roles in which they will use and express themselves physically, cognitively, emotionally, and mentally during performing their roles. M. Bakker, (2006) said that working engagement is characterized by high energy levels and can be identified with one's work.

Mcbain (2006) said that employee engagement reflects changes in organizational contexts in which employees and businessmen in a psychological contract reflect motivational patterns that change for greater personal fulfillment in their working lives and are not solely motivated by financial rewards. Working engagement provides important personal resources needed to initiate new behavior (Salanova, 2008). Engagement is identified by the commitment to an organization or a job by applying requirements such as organizational commitment and satisfaction. Employee engagement is based on organizational culture, communication style, managerial style, leadership style, and trust (Lockwood, 2007).

According to Schaufeli, Salanova, González-romá, \& Bakker (2002) employee engagement as a condition that can motivate to work is characterized by enthusiasm, dedication, and absorption. The involved employees have an energetic and effective relationship with their working activities and see themselves able to fully handle the demands of their work. Schaufeli et al., (2002) claimed that working engagement that involves strength, dedication, and absorption shows high energy and motivation during the working activities. Dedication is characterized by a perception of meaning, inspiration, and pride in one's work. Furthermore, absorption is associated with being fully concentrated and enjoying a job in which time passes quickly and someone has difficulty getting away from the job.

The Relationship between Transformational Leadership and Engagement

Bass (1985) stated that transformational leaders can improve performance to be higher. Based on a study conducted by Kovjanic et al (2013), it indicated that there is a relationship between transformational leadership and working engagement proven empirically; however, it is still in a relatively limited condition. Working engagement provides important personal 
resources needed to initiate new behavior (Salanova, 2008). Transformational leaders tend to stimulate the employees' working engagement by giving meaning to their work.

Therefore, transformational leaders can articulate a vision that focuses on achievement related to their goals and concern and supports their followers. This will have a positive impact on employee engagement (Breevaart et al., 2014; Den Hartog \& Belschak, 2012; Kovjanic et al., 2013). Transformational leaders also tend to stimulate employees' working engagement by giving meaning to their followers' work. In addition, they tend to express optimism, spirit, and enthusiasm in the workplace (Den Hartog \& Belschak, 2012). Based on the strong attachment between leaders and followers, transformational leaders try to change the personal values of followers so that they can expand and increase their needs and aspirations to focus and achieve higher and potential levels of need (Avolio \& Bass, 1988; Bass, 1985).

$\begin{aligned} \text { Hypothesis 1: } & \text { There is a positive } \\ & \text { relationship between } \\ & \text { transformational leadership } \\ & \text { and engagement. }\end{aligned}$

The Relationship between Engagement and Performance

Based on a study conducted by Bakker \& Bal (2010), there is a relationship between engagement and performance. Some studies also show that engagement has a positive relationship with business unit performance (Halbesleben \& Wheeler, 2008; Schaufeli, Taris, \& Bakker,

2006). A study conducted by A. B. Bakker, Demerouti, \& Ten Brummelhuis (2012) indicated that engagement only facilitates performance when employees get high scores on perseverance and self-discipline (i.e. self-awareness).

$\begin{array}{rrr}\text { Hypothesis 2: } & \text { There is a positive } \\ & \text { relationship } \\ \text { engagement } & \text { between } \\ \text { performance. } & \text { and }\end{array}$

Relationship between Transformational Leadership and Performance

Based on a study conducted by Wang, Oh, Courtright, \& Colbert (2011), transformational leadership has a positive relationship on performance. Previous studies also showed that transformational leadership improves performance related to employee's tasks (Kovjanic et al., 2013). A study conducted by Wang, Oh, Courtright, \& Colbert (2011) indicated that transformational leadership has a positive relationship on performance. Several studies have shown the influence of transformational leadership on performance. A study conducted by García-Morales, Jiménez-Barrionuevo, \& Gutiérrez-Gutiérrez (2012) indicated that transformational leadership influences performance. Furthermore, a study conducted by Para-González, Jiménez-Jiménez, \& MartínezLorente (2018) also showed a similar result in which transformational leadership again influences performance.

$\begin{aligned} & \text { Hypothesis 3: } \text { There is a positive } \\ & \text { relationship between } \\ & \text { transformational leadership } \\ & \text { and performance. }\end{aligned}$

Research Model

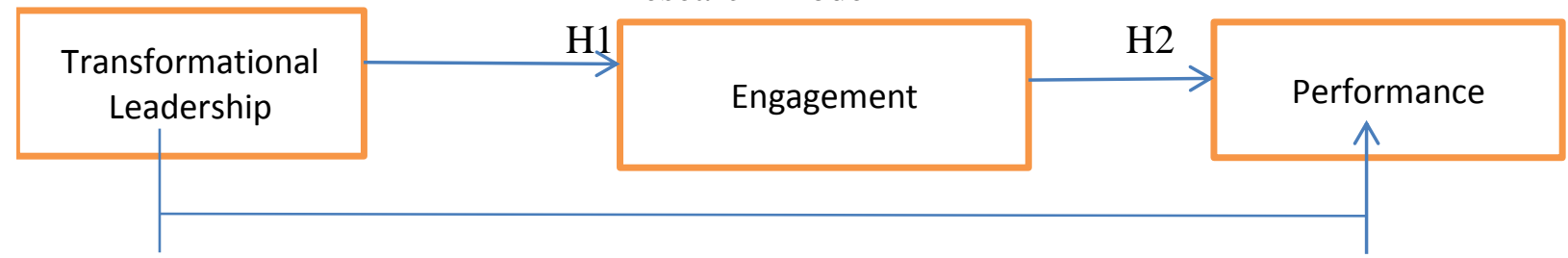

\section{RESEARCH METHOD}

This research uses SEM. A structural equation modeling (SEM) is a statistical methodology that applies a confirmation approach (e.g. hypothesis testing) for structural theory analysis that involves several phenomena (Byrne, 
2011). Hair, Ringle, \& Sarstedt (2011) stated that PLS-SEM is a causal modeling approach that aims to maximize the variance from dependent latent constructs. The population in this study were lecturers from all over Indonesia and at the same time there were dosesn located on several campuses. This research uses quantitative research.

\section{RESULTS}

\section{Outer Model Analysis}

The outer model analysis specifically focuses on the relationship between latent variables and their indicators. In other words, the outer model analysis defines how each indicator relates to its latent variable. Tests carried out on the outer model analysis are as follows.

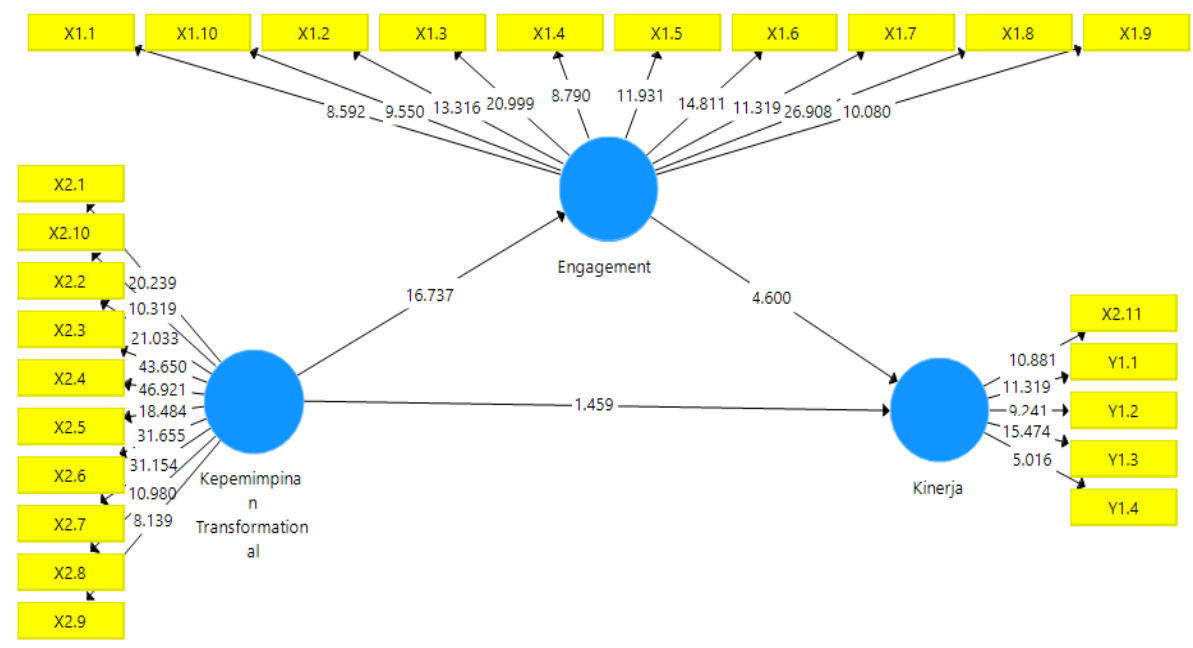

1. Convergent Validity

Convergent validity is used for indicator validation of the variables seen from the loading factor value. It is considered to be accepted if the loading factor value is above 0.7 with a minimum value of 0.5 .

\section{Engagement Transformational Performance}

\begin{tabular}{llll}
\hline & \multicolumn{1}{c}{ Leadership } & Note \\
\hline X1.1 & $\mathbf{0 . 7 2 9}$ & Passed \\
\hline X1.2 & $\mathbf{0 . 7 6 4}$ & Passed \\
\hline X1.3 & $\mathbf{0 . 7 9 2}$ & Passed \\
\hline X1.4 & $\mathbf{0 . 8 2 1}$ & Passed \\
\hline X1.5 & $\mathbf{0 . 7 5 2}$ & Passed \\
\hline X1.6 & $\mathbf{0 . 6 0 9}$ & Passed \\
\hline X1.7 & $\mathbf{0 . 7 2 9}$ & Passed \\
\hline X1.8 & $\mathbf{0 . 7 4 9}$ & Passed \\
\hline X1.9 & $\mathbf{0 . 8 3 4}$ & & Passed \\
\hline X1.10 & $\mathbf{0 . 6 6 9}$ & Passed \\
\hline X2.1 & & Passed \\
\hline X2.2 & $\mathbf{0 . 8 3 5}$ & Passed \\
\hline X2.3 & $\mathbf{0 . 7 1 4}$ & Passed \\
\hline X2.4 & $\mathbf{0 . 6 9 8}$ & Passed \\
\hline X2.5 & $\mathbf{0 . 8 3 3}$ & Passed
\end{tabular}




\begin{tabular}{lll} 
X2.6 & $\mathbf{0 . 8 9 8}$ & Passed \\
\hline X2.7 & $\mathbf{0 . 7 7 7}$ & Passed \\
\hline X2.8 & $\mathbf{0 . 8 7 7}$ & Passed \\
\hline X2.9 & $\mathbf{0 . 8 7 9}$ & Passed \\
\hline X2.10 & $\mathbf{0 . 7 5 6}$ & Passed \\
\hline X2.11 & $\mathbf{0 . 6 6 7}$ & Passed \\
\hline
\end{tabular}

\begin{tabular}{lll}
\hline Y1.1 & $\mathbf{0 . 8 4 0}$ & Passed \\
\hline Y1.2 & 0.833 & Passed \\
\hline Y1.3 & $\mathbf{0 . 8 3 3}$ & Passed \\
\hline Y1.4 & $\mathbf{0 . 7 0 1}$ & Passed
\end{tabular}

The final check of convergent validity is to consider the AVE value. The indicator is considered to have a good convergent validity if it has an AVE value of more than 0.5. In the validity test, the corrected item-total correlation value is also referred to as the $r$ count value. The basis of decision making in the validity test applies the following criteria. If $r$ count $>r$ table, the questionnaire is valid. If $r$ count $<r$ table, the questionnaire is invalid. $\mathrm{df}=(\mathrm{N}-2)=r$ table of 0.2090

\section{Discriminant Validity}

Validity illustrates the accuracy of research and can be subdivided into different concepts.
In quantitative research, validity must claim for a wider population and not just samples (Golafshani, Nahid., 2003).The discriminant validity is the measurement model with reflective indicators that is assessed by comparing the Average Variance Extracted (AVE) of the square root values of each construct with the correlation between one construct and other constructs in the model. If the results of the AVE square root value of each construct are greater than the correlation value between one construct and other constructs in the model, it can be considered that it has a good discriminant validity value (Ghozali,

AVE AVE Root

\begin{tabular}{lcc}
\hline Engagement & 0.559 & 0.748 \\
\hline $\begin{array}{l}\text { Transformational } \\
\text { Leadership }\end{array}$ & 0.666 & 0.816 \\
\hline Performance & 0.614 & 0.784
\end{tabular}

3. Composite Reliability

Data that has composite reliability of > 0.7 has high reliability.

4. The construct reliability test is carried out by measuring two criteria, i.e. composite reliability and Cronbach's alpha. The construct is considered to be reliable if the composite reliability and Cronbach's alpha values are above 0.7 .
5. The results of the composite reliability and Cronbach's alpha test are presented in the following table. From the table, it can be seen that all variables have composite reliability above 0.7. Furthermore, in this study, the reliability test was strengthened by Cronbach's alpha test. The expected value is > 0.6 for all constructs (Gozali, 2011). 


\begin{tabular}{lccc} 
& \multicolumn{2}{c}{ Composite } & \multicolumn{2}{c}{ Cronbach's } \\
Reliability & Alpha & \\
Engagement & 0.926 & 0.911 & $\begin{array}{l}\text { Reliable } \\
\text { Reliable }\end{array}$ \\
Transformational & & & \\
Leadership & 0.952 & 0.943 & Reliable \\
Performance & 0.888 & 0.841 &
\end{tabular}

6. Average Variance Extracted (AVE). The expected AVE value is $>0.5$.

\begin{tabular}{|c|}
\hline $\begin{array}{l}\text { Average } \\
\text { Variant } \\
\text { Extracted } \\
\text { (AVE) }\end{array}$ \\
\hline \\
\hline
\end{tabular}

\section{A. Inner Model Analysis}

Engagement

Transformational

Leadership

Performance

Evaluation of inner models can be conducted in three methods. Those three methods are by considering the values of R2, Q2, and GoF.

R Square

\begin{tabular}{lrr} 
& R Square & \multicolumn{2}{c}{ Adjusted } \\
\hline Engagement & 0.672 & 0.669 \\
\hline Performance & 0.572 & 0.563
\end{tabular}

The value of engagement shown in the table above is 0.669 meaning that engagement is able to explain the variance of $66.9 \%$. The value of performance is 0.563 meaning that performance is able to explain the variance of $56.3 \%$. Furthermore, the rest is explained by other constructs outside that examined in this study.

\section{Q2 Predictive Relevance}

Besides considering the size of the R-square, evaluation of the PLS model can also be conducted with Q2 predictive relevance or predictive sample reuse to represent synthetically from cross-validation and fitting functions with predictions from observed variables and estimates of construct parameters. If the Q2 value is > 0, it indicates that the model has predictive relevance. Meanwhile, if the Q2 value is < 0, it indicates that the model has less predictive relevance (Ghoali and Latan, 2015). Q2 measures how well the observation values generated by the model and also estimated its parameters.

Furthermore, to test the inner model, it can be conducted by considering the value of $Q^{2}$ (predictive relevance). To calculate $Q^{2}$, the formula that can be used is as follows.

$$
\begin{aligned}
& Q^{2}=1-\left(1-R^{2}\right) \\
& Q^{2}=1-\left(1-0,696^{2}\right) \\
& Q^{2}=0.484
\end{aligned}
$$

The Goodness of Fit (GoF) Test

The result of the GoF test is obtained from the multiplication of the average root value of commonalities with the average root value of r-square. From the GoF calculation, it obtained values of 0.526 for engagement and 0.447 for performance. Therefore, it can be concluded that the model has a greater GoF. 
Furthermore, the greater the GoF value is, the more appropriate it is to describe the research sample. The last is to find out the value of the Goodness of Fit (GoF). In contrast to CBSEM, for the GoF value on PLS-SEM, it must be sought manually.

$$
\text { 1. } \begin{aligned}
\mathrm{GoF} & =\sqrt{0.613 \times} 0,672^{2} \\
\mathrm{GoF} & =0.526 \\
\text { 2. } \mathrm{GoF} & =\sqrt{0.613 \times} 0,572^{2} \\
\mathrm{GoF} & =0.447
\end{aligned}
$$$$
\mathrm{GoF}=\sqrt{A V E x R^{2}} \text {........Tenenhaus (2004) }
$$

According to Tenenhau (2004), the GoF is used to validate the combined performance of the measurement model (outer model) and structural model (inner model) in which its value ranges between $0-1$. The interpretation of values is $0-0.25$ indicating a small GoF, 0.25-0.36 indicating a moderate GoF, and above 0.36 indicating a great $\mathrm{GoF}$.

B. Hypothesis Testing

Evaluation of Structural Models (inner model)

Path Coefficients

Mean, STDEV, T-Values, $P$-Values

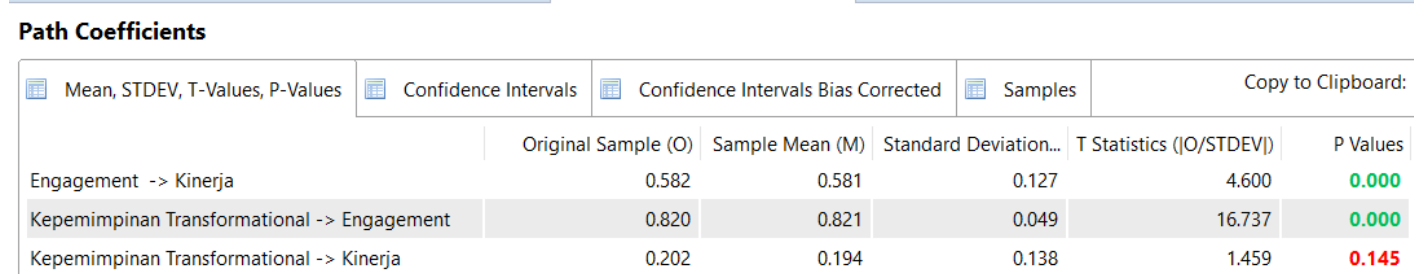

After testing the measurement model (outer model), the next step is testing on the structural model (inner model) to find out whether the hypothesis can be accepted or rejected. This study will use a significant value $(\alpha)$ of 0.05 or $5 \%$. Relationships between variables can be considered significant if the $P$ value is smaller than the predetermined significant value $(P<0.05)$.

\section{CONCLUSIONS}

Based on the analysis above, it can be concluded that the hypothesis of this study that the relationship between engagement and performance is significant with a T-statistic value of 4.000 (> 1.96). Furthermore, the original sample estimate value is positive that is 0.582 which indicates that the relationship between engagement and performance is positive. Therefore, hypothesis 1 is accepted. This is in line with a study conducted by Halbesleben \& Wheeler (2008) that there is a relationship between engagement and performance. In addition, the results of hypothesis testing also indicated that the relationship between transformational leadership and engagement is significant with a T-statistic value of 16.737 (> 1.96). Furthermore, the original sample estimate value is positive that is 0.820 which indicates that the relationship between transformational leadership and engagement is positive. Therefore, hypothesis 2 is accepted. This is in line with a study conducted by Vincent-Höper, Muser, \& Janneck (2012) that there is a relationship between transformational leadership and engagement

For the last result of hypothesis testing, it indicated that the relationship between transformational leadership and performance is not significant with a T-statistic value of 0.145 (< 1.96). Meanwhile, the original sample estimate value is positive that is 0.202 which indicates that the relationship between transformational leadership and performance is negative. Therefore, hypothesis 3 is rejected. This is in line with a study conducted by Ross \& Offermann, (1997), Thoni Setyo Prabowo (2018), and Eliyana, Ma'arif, \& Muzakki (2019) that transformational leadership has no effect on performance. Furthermore, a study conducted by Ross \& Offermann (1997) even indicated that there is no significant relationship between transformational 
leadership and performance in the academic, athletic, or military fields

\section{REFERENCES}

[1] Avolio, B. J., Waldman, D. A., \& Einstein, W. O. Transformational Leadership in a Management Game Simulation: Impacting the bottom line. Group \& Organization Management, 13(1), 59-80 (1998). https://doi.org/10.1177/10596011880130010 9

[2] Azka, G., Tahir, M. Q., M, A. K., \& Syed, T. H. Transformational leadership, employee engagement and performance: Mediating effect of psychological ownership. African Journal of Business Management, 5(17), 7391-7403

(2011).

https://doi.org/10.5897/ajbm11.126

[3] Bakker, A. B., \& Bal, P. M. Weekly work engagement and performance: A study among starting teachers. Journal of Occupational and Organizational Psychology, 83(1), 189-206 (2010).

https://doi.org/10.1348/096317909X402596.

[4] Bakker, A. B., Demerouti, E., \& Ten Brummelhuis, L. L. (2012). Work engagement, performance, and active learning: The role of conscientiousness. Journal of Vocational Behavior, 80(2), 555564 (2012).

https://doi.org/10.1016/j.jvb.2011.08.008

[5] Bakker, M. Is trust really social capital? Knowledge sharing in product development projects. Learning Organization, 13(6), 594605.

https://doi.org/10.1108/09696470610705479 (2006).

[6] Bass, B. M. Leadership: Good, better, best. Organizational Dynamics, 13(3), 26-40. https://doi.org/10.1016/0090-2616(85)900282 (1985)

[7] Bass, B. M., Avolio, B. J., \& Goodheim, L. Biography and the Assessment of Transformational Leadership at the WorldClass Level. Journal of Management, 13(1), 7-19. https://doi.org/10.1177/01492063870130010 2 (1987)

[8] Buil, I., Martínez, E., \& Matute, J. Transformational leadership and employee performance: The role of identification, engagement and proactive personality. International Journal of Hospitality Management, 77(June 2018), 64-75. https://doi.org/10.1016/j.ijhm.2018.06.014 (2019)

[9] Byrne, B. M. Structural equation modeling with Mplus : basic concepts, applications, and programming. Multivariate applications series (2011)

[10] Den Hartog, D. N., \& Belschak, F. D. When does transformational leadership enhance employee proactive behavior? The role of autonomy and role breadth self-efficacy. Journal of Applied Psychology, 97(1), 194202. (2012) https://doi.org/10.1037/a0024903

[11] Eliyana, A., Ma'arif, S., \& Muzakki. Job satisfaction and organizational commitment effect in the transformational leadership towards employee performance. European Research on Management and Business Economics, 25(3), 144-150. (2019) https://doi.org/10.1016/j.iedeen.2019.05.001

[12] García-Morales, V. J., Jiménez-Barrionuevo, M. M., \& Gutiérrez-Gutiérrez, L. (2012). Transformational leadership influence on organizational performance through organizational learning and innovation. Journal of Business Research, 65(7), 1040 1050 https://doi.org/10.1016/j.jbusres.2011.03.005

[13] Golafshani, Nahid. Understanding reliability and validity in qualitative research. The Qualitative Report, 8(4), 597-607.(2003)

[14] Hair, J. F., Ringle, C. M., \& Sarstedt, M. PLS-SEM: Indeed a silver bullet. Journal of Marketing Theory and Practice, 19(2), 139152.

https://doi.org/10.2753/MTP10696679190202 
[15] Halbesleben, J. R. B., \& Wheeler, A. R. The relative roles of engagement and embeddedness in predicting job performance and intention to leave. Work and Stress, 22(3), 242-256. (2008)

https://doi.org/10.1080/02678370802383962

[16] Kahn, W. A. Slow-mode surface plasma oscillations in layered structures. Physical Review B, 36(5), 2607-2613. (1990) https://doi.org/10.1103/PhysRevB.36.2607

[17] Kovjanic, S., Schuh, S. C., \& Jonas, K. Transformational leadership and performance: An experimental investigation of the mediating effects of basic needs satisfaction and work engagement. Journal of Occupational and Organizational Psychology, 86(4), 543-555.(2013)

https://doi.org/10.1111/joop.12022.

[18] Macey, W. H., \& Schneider, B. The Meaning of Employee Engagement. Industrial and Organizational Psychology, 1(1), 330.(2008)https://doi.org/10.1111/j.17549434.2007.0002.x

[19] Mcbain, R. Employee Engagement - the Emergence of a New Construct? Henley Manager Update, 17(4), 21-33. (2006) https://doi.org/10.1177/17457866060170040 3

[20] Para-González, L., Jiménez-Jiménez，D., \& Martínez-Lorente, A. R. Exploring the mediating effects between transformational leadership and organizational performance. Employee Relations, 40(2), 412-432.(2018) https://doi.org/10.1108/ER-10-2016-0190

[21] Ross, S. M., \& Offermann, L. R. Transformational leaders: Measurement of personality attributes and work group performance. Personality and Social Psychology Bulletin, 23(10), 10781086.(1997)

https://doi.org/10.1177/01461672972310008

[22] SUSANTI, S., Anik, I., \& Edi, P. (2020). An Approach for Supply Chain Managing of Small and Big Size Business. International
Journal of Supply Chain Management (IJSCM), 9(2), 1014-1017.

[23] Salanova, W. B. S. and marisa. Enhancing work engagement through the managment of human resources. Virus Genes. (2008) https://doi.org/10.1007/s11262-004-5626

[24] Samad, S. The Influence of Innovation and Transformational Leadership on Organizational Performance. Procedia Social and Behavioral Sciences, 57, 486-493. (2012) https://doi.org/10.1016/j.sbspro.2012.09.121

[25] Sandell, K. Transformational Leadership, Engagement, and Performance: a New Perspective. MSc Thesis, Colorado State Univ, 1 to 97 (2012.

[26] Schaufeli, W., Salanova, M., González-romá, V., \& Bakker, A. The Measurement of Engagement and Burnout: A Two Sample Confirmatory Factor Analytic Approach. Journal of Happiness Studies, 3(1), 71-92 (2002) https://doi.org/10.1023/A:1015630930326

[27] Thoni Setyo prabowo, D. W. I. the Influence of Transformational Leadership and Work Motivation on Employee Performance Mediated By Job Satisfaction. Jurnal Aplikasi Manajemen, 16(1), 171-178. (2018) https://doi.org/10.21776/ub.jam.2018.016.01. 20

[28] Vincent-Höper, S., Muser, C., \& Janneck, M. Transformational leadership, work engagement, and occupational success. Career Development International, 17(7), 663-682.(2012) https://doi.org/10.1108/13620431211283805

[29] Wang, G., Oh, I. S., Courtright, S. H., \& Colbert, A. E. Transformational leadership and performance across criteria and levels: A meta-analytic review of 25 years of research. Group and Organization Management, 36(2), 223-270. (2012) https://doi.org/10.1177/105960111140101 